\title{
Invasions and re-emergences: an analysis of the success of Bythotrephes in Lago Maggiore (Italy)
}

\author{
Marina MANCA \\ CNR Institute of Ecosystem Studies, Largo Tonolli 50, I - 28922 Verbania, Italy \\ e-mail:m.manca@ise.cnr.it
}

\begin{abstract}
Bythotrephes was first seen in North America in 1982 (single individual, Lake Ontario) and noticed elsewhere in the Laurentian Great Lakes in abundance in 1985. Starting from 1987 it sharply increased in the open-water zooplankton of Lago Maggiore, reaching values never recorded in the past 40 years. Despite being native, the species' impact on Lago Maggiore was somewhat comparable to that observed in invaded North American lakes. The re-emergence led to an overall increase in invertebrate predation which became permanent five years after Bythotrephes' establishment, causing direct and indirect effects on the food web. Changes included a sharp decrease in the large filter-feeder Daphnia, whose mortality rate increased, and consequently an increase in phytoplankton cell density; an increase in abundance and size of colonial rotifers with a decline in Leptodora abundance, and an overall decrease in zooplankton biomass were also observed. The increase of Bythotrephes in Lago Maggiore, however, was related to a shift in population phenology, which resulted in seasonal growth starting earlier and lasting longer. Daphnia phenology changed only later, suggesting that the impact was consequent to a temporary decoupling between Bythotrephes and its preferred prey. The shift in density and phenology became permanent. Over the long-term, however, potential competitors and prey were able to recover, reaching levels of abundance comparable to those recorded before the Bythotrephes' re-emergence. Such a response is likely attributable to behavioural adaptation mechanisms resulting in temporal and spatial displacement of potential competitors, predators and prey.
\end{abstract}

Key words: Bythotrephes, re-emergence; zooplanktivorous fish; population phenology

\section{INTRODUCTION}

Bythotrephes longimanus (Leydig), the palearctic predator which has invaded more than 200 lakes in North America, is indigenous to European subalpine lakes (Ishreyet 1938; Hovius et al. 2007). Originally reported from Lake Constance, it was first recorded not as zooplankton, but as part of the stomach content of Coregonus wartmanni, the zooplanktivore most commonly fished commercially (in Sars 1861). In his original description, reflected in the name he attributed to this large cladoceran, Leydig (1860) emphasized a behavioural attribute of the species - a preference for the deep epilimnion - and its most important anatomical feature, a long tail spine, from which the common name "spiny water flea" derives.

These historical data are also reflected in the research performed on Bythotrephes in Lago Maggiore. Before the establishment in the late seventies of the International Commission for the Protection of Lago Maggiore waters, which prompted a long-term monitoring program of the Lago Maggiore pelagic community, including zooplankton, studies dealing with Bythotrephes largely focused on its role in the diet of zooplanktivorous fish, mainly whitefish species (Giussani 1974). Not only was Bythotrephes found to compose more than $80 \%$ of whitefish stomach content in late summer and fall (expressed as relative abundance, therefore presumably much more when expressed as contribution to total biomass), it also appeared to be more detectable earlier in the season and for a longer time in the fish stomaches than in zooplankton samples taken in open-water. This pattern suggests that the Bythotrephes population was subject to strong pressure from zooplanktivores.

The effects of fish predation pressure were clear when the body size of the prey in fish stomachs was compared with its body size in open water; though it was less clear when it came to explaining changes in Bythotrephes abundance in the water column, which were overlooked given the very low levels and the short growth period of the planktonic population (Giussani 1974). In fish stomachs, Bythotrephes body length was significantly higher (between 1775 and $1900 \mu \mathrm{m}$, from late summer to fall) than in open water, where it ranged between 1650 and $1820 \mu \mathrm{m}$ during the same period (Giussani, ibidem).

The marginal role of Bythotrephes in studies on Lago Maggiore zooplankton was further emphasized after a monitoring program was set up following the eutrophication of the lake (de Bernardi et al. 2000). The enrichment in algal nutrients led to Leptodora kindtii (Focke), the predatory Cladocera which coexisted with Bythotrephes, becoming by far the most prevalent predatory cladoceran in the lake (e.g., Manca et al. 1992). Its impact on the abundance and population dynamics of Daphnia, the most efficient filter-feeder in 
the pelagia of the lake, became the main focus of the research activity on Lago Maggiore zooplankton (de Bernardi et al. 1990).

It was only with its unexpected, sharp increase in abundance during re-oligotrophication that $B$. longimanus began to be regarded as a non-negligible component of Lago Maggiore's zooplankton population as well as of the whitefish diet (Manca et al. 2008). Its increase was so successful that it is justifiable to describe it as a re-emergence. A re-emergence may have an impact comparable to that of an invasion; it differs, however, because the invasion process lacks of an evolutionary history and a co-adaptation between the predator and the prey. The latter is also likely characterized by a low genetic variability. Because of its invasive nature, and the huge effort made to study all the possible implications of its invasion, most of our present knowledge on Bythotrephes as a predatory zooplankter comes from studies on invaded sites. These studies made a major contribution to understanding the impact of the species' increase on the Lago Maggiore pelagic environment.

In this paper, I will review evidence of the direct and indirect effects of the increase of Bythotrephes in Lago Maggiore, discussing the most striking changes in zooplankton and phytoplankton observed along with its success. I shall present historical data from the early $20^{\text {th }}$ Century, following which I will focus mainly on the period of Bythotrephes increase (1983-1995) for which data on the commercial fish catch are also available. The impact of its re-emergence in Lago Maggiore will be compared with the pattern observed in invaded lakes elswhere, also in view of an identification of mechanisms responsible for its recent success.

\section{MATERIALS AND METHODS}

Zooplankton data from the early $20^{\text {th }}$ Century were taken from Baldi et al. (1953; in Manca et al. 1992). I used only data from samples collected at the same station (Ghiffa), where the lake reaches its maximum depth $(370 \mathrm{~m})$, and which has historically been used as representative of the pelagic planktonic community (de Bernardi 1974). All samples were collected with a ClarkeBumpus plankton sampler, fitted with a $76 \mu \mathrm{m}$ nylon net, towed down to $50 \mathrm{~m}$ depth and up to surface, from a boat moving at a low, constant cruise speed $\left(0.6 \mathrm{~m} \mathrm{~s}^{-1}\right)$, to allow for the filtration of at least $1000 \mathrm{~L}$ of lake water on a sinusoidal trajectory. The integrated samples were representative of the pelagic crustacean zooplankton, during the day in major part distributed within the upper $50 \mathrm{~m}$ depth (de Bernardi et al. 1988). The sampling frequency was the same from the 1980s onward: at least monthly, and fortnightly or weekly in spring and summer (Manca \& Ruggiu 1998).

Samples were preserved in pure (99\% volume) ethanol and counted. For some years of the period, Daphnia clutch size was recorded, and body length (from the apex of the head to the base of the carapace spine) measured on 200 individuals, or, when fewer, on the total number of individuals in the sample. The minimum size at maturity (MSP), taken as the minimum body length of ovigerous females, and the maximum size (MS) were also estimated in each sample. Bythotrephes body and tail spine lengths were measured for some years (1988, 1992-93, 1996-97, 2001; Manca \& Comoli 1988; Manca et al. 2000; Manca et al. 2008; data not shown), and the clutch size of ovigerous females estimated after extruding embryos from the mother's brood pouch, to allow them to be counted and measured (1983-1988 and 1992). Per capita mortality and death rates of Daphnia and Bythotrephes were calculated from Paloheimo's equation (Paloheimo 1974), using mean water temperature of the sampled layer to estimate the developmental time of embryos (Manca et al. 2000; Yurista 1992).

The Statsoft program Statistica version 6 was used to analyze the data. We tested the statistical significance of correlations (Pearson's $r$ ) between Bythotrephes mean annual density and population phenology and abundance and biomass of potential prey and competitors.

\subsection{Study lake}

Lago Maggiore is the second largest $\left(212.5 \mathrm{~km}^{2}\right)$ and deepest (maximum depth $370 \mathrm{~m}$, mean depth $171 \mathrm{~m}$ ) subalpine lake in Italy (194 m a.s.l.). Oligotrophic by nature, the lake became mesotrophic in the 1970s. Its slow recovery from eutrophication, due to the gradual implementation of sewage treatment plants and the reduction of the phosphorus content in detergents in the 1980 s, has been documented in a long series of papers and technical reports (e.g., de Bernardi et al. 1990; Manca et al. 2007). During re-oligotrophication, total phosphorus (TP) and reactive phosphorus (RP) concentrations (measured at the winter mixing) decreased from 38 and $28 \mu \mathrm{g} \mathrm{L}^{-1}$, respectively to $c a 20$ and $13 \mu \mathrm{g} \mathrm{L}^{-1}$ in the late $1980 \mathrm{~s}$, approaching values of 10 and $6 \mu \mathrm{g} \mathrm{L}^{-1}$ in the mid 1990s (Fig. 1A). Since 1995 TP averages $10 \mu \mathrm{g}$ $\mathrm{L}^{-1}$. Chlorophyll- $a$ concentration (mean annual value) also decreased, more sharply in the first half of the $1990 \mathrm{~s}$, from ca $5 \mathrm{mg} \mathrm{m}^{-3}$ to $c a 3 \mathrm{mg} \mathrm{m}^{-3}$ (Manca \& Ruggiu 1998).

\section{RESULTS AND DISCUSSION}

Although Lago Maggiore used to be defined as a "Copepod lake", it was Cladocera that actually typified its trophic evolution (de Bernardi et al. 1990). With data available from the middle of the $20^{\text {th }}$ Century on, we can trace the change from the original cladoceran community of the pre-eutrophication years and the community established during the mesotrophic phase, and compare both of them with the community established when the lake returned to oligotrophy (Fig. 1B). In the middle of the $20^{\text {th }}$ Century, the mean annual abundance of Bythotrephes was fully comparable to that of Leptodora. The latter became far more prevalent, along with the large 

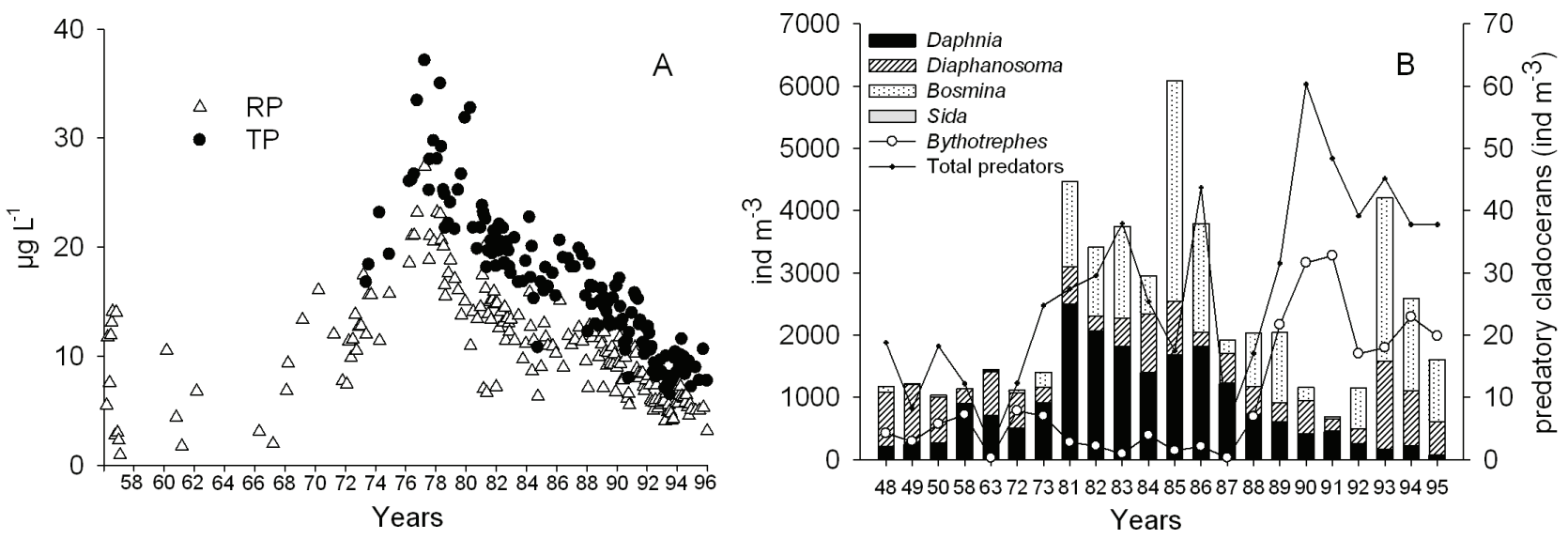

Fig. 1. (A) Long-term changes in total (TP) and reactive (RP) phosphorus concentrations and (B) long-term changes in Cladocera abundance and taxa composition. in Lago Maggiore.
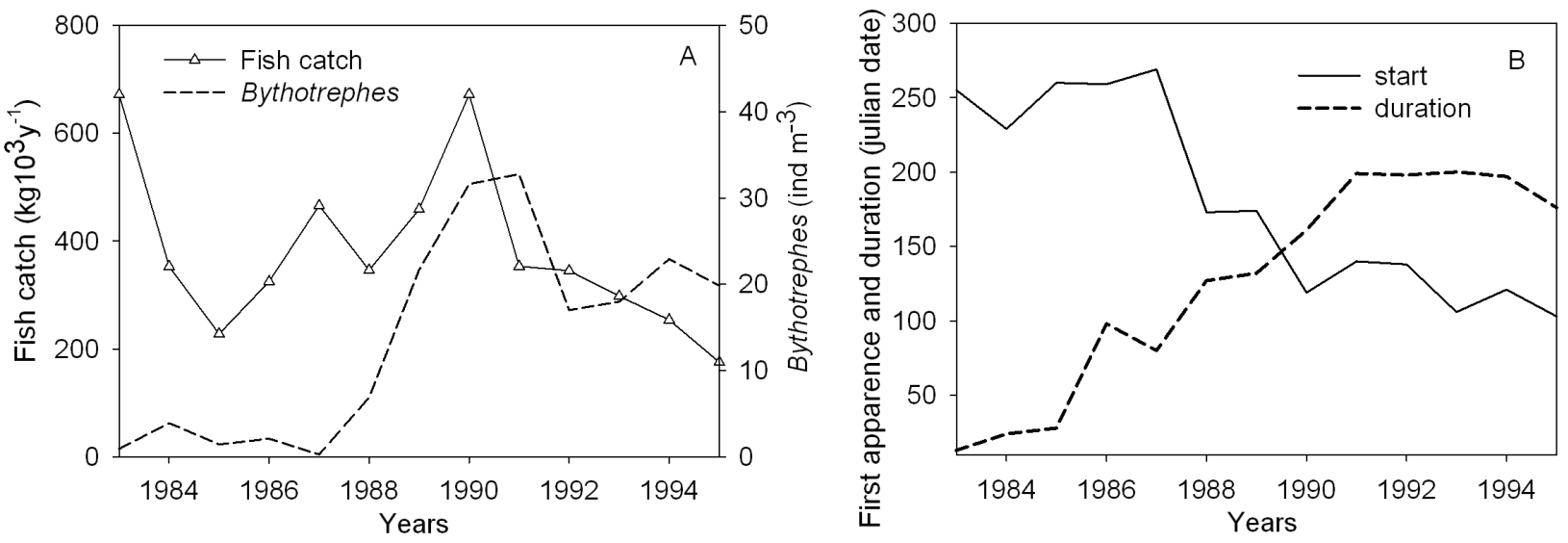

Fig. 2. Changes in mean annual Bythotrephes population density and commercial catch of non-piscivorous fish (data from Grimaldi 1997) (A); time at growing start and of duration of Bythotrephes planktonic population (B).

filter feeder Daphnia, during mesotrophy (1970s-mid 1980s).

The one-order-of magnitude increase in abundance of Bythotrephes from 1988 to 1990, during the reoligotrophication of the lake, led to a substantial change in the Cladocera community, which became permanent, and resulted in an increase in abundance of invertebrate predators to levels never reached before. Leptodora population density was low in 1987-1988 (Manca et al. 1992); however, its decrease was not such as to counterbalance the increase of Bythotrephes. A temporary low density of the potential competitor Leptodora might be regarded as a favourable condition for the successful increase of Bythotrephes. The success of an invader (i.e. the "when" of a successful invasion) is often associated with the decrease of a potential competitor - a "temporary condition of advantage", which might favour invasion, in the same way as happened with the spread of Daphnia hybrids in European lakes (Hoekstra \& Spaak1995). A similar mechanism was found to explain the recent successful invasion of Lago Maggiore by Eudiaptomus gracilis, which has supplanted the native Mixodiaptomus laciniatus (Visconti \& Manca 2010).
Unlike what has been observed in some invaded lakes (Foster \& Sprules 2009), however, Bythotrephes population density is not inversely correlated at a statistically significant level with that of Leptodora in Lago Maggiore.

The Bythotrephes increase occurred when the pelagic fish stock was not decreasing [data on commercial fish catch from Grimaldi (1997); Fig. 2A]. The result is also consistent with previous studies, and with data from invaded lakes; according to the latter, amongyear variations in Bythotrephes level of population density could not be predicted at a reasonable level of statistical significance from changes in zooplanktivorous fish stock (Yan \& Pawson 1998; Yan et al. 2001). Instead, in Lago Maggiore, whitefish (data from commercial fishing catch) seem to have increased between 1988 and1990, reaching a level quite similar to that recorded in 1983 (Fig. 2A). Such an increase might have been favoured by an increased growth rate consequent to higher availability over the year of their preferred, large-sized food item. The sharp decrease in fish commercial catch in 1991, and the gradual decline in the following years, might be partly attributable to the 

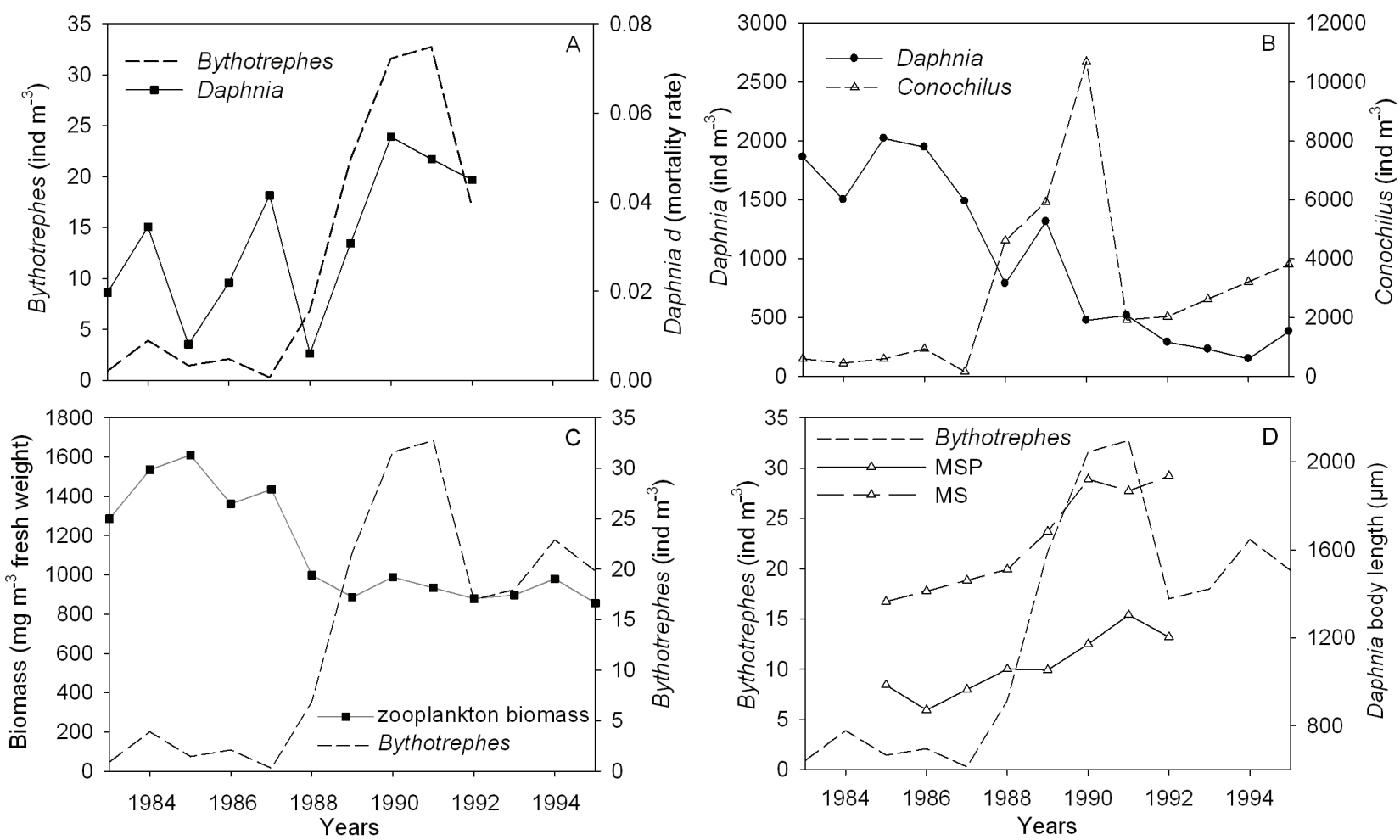

Fig. 3. (A) Bythotrephes population density and Daphnia per capita mortality rate; (B) Daphnia and Conochilus population densities (1983-1995) (from Manca \& Sonvico 1996); C) Bythotrephes abundance and zooplankton biomass; D) Daphnia body size (length; for explanation of MSP and MS see methods) and Bythotrephes abundance. All panels refer to the period 1983-1995.

oligotrophication process because of the delayed response of zooplanktivores compared to planktonic organisms, as a consequence of their longer generation times. Studies on Bythotrephes-invaded lakes, however, also suggest that an overall increase in predatory cladocerans might result in an increase in competition with young fish for herbivorous zooplankton (Dimitru et al. 2001). The increase in growth efficiency of the young fish resulting from their consumption of larger prey might not be sufficient to offset the negative effect of the increased competition with invertebrate predators (Foster \& Sprules 2009).

The increase in abundance of Bythotrephes in Lago Maggiore was related to major changes in phenology, with an earlier start, and a longer persistence, of the population in the water column (Fig. 2B). Time at start was correlated with mean and maximum year population densities, as well as with the time at which the density peak was reached (Yan \& Pawson 1998; Manca \& DeMott 2009).

During the increase, the mean annual per capita mortality rate of the Bythotrephes population decreased (data not available for all the years). It was on average 0.23 in 1983-1986, declined to 0.17 in 1987-1988 and then to 0.10 in 1992 . The per capita mean annual birth rate increased from 0.17 to 0.24 between 1985 and 1987, before the increase in abundance, decreasing to 0.20 and 0.08 in 1988 and 1992, respectively.
The Bythotrephes increase was accompanied by a decrease in the Daphnia population density (Fig. 3A). The mean annual abundance of the predator and its preferred prey were negatively correlated at a high level of significance (Spearman $r=-0.76 ; \mathrm{n}=13 ; p<0.01$ ). This result is consistent with published reports on the effects of invasive Bythotrephes on the open water Cladocera community in North America lakes (Lehman 1988; Pangle et al. 2007). In Lago Maggiore, however, the impact on Daphnia was related to an initial change in phenology of Bythotrephes, a change which was not initially observed for the prey. Daphnia peak timing remained quite stable, around Julian day 200, in 19831990 , but decreased by about two months only as of 1991 (Visconti et al. 2008). The earlier start of seasonal growth and peak density of Bythotrephes exposed Daphnia to early predation, most probably also on ovigerous females, which are usually abundant before the population density peak. Before the Bythotrephes reemergence, Daphnia had been able to cope with a strong predation pressure by Leptodora, mainly directed towards young (de Bernardi 1974), which caused a sharp decline in population density in late July-August. This decline, however, was linked to an increase in the birth rate of the prey (a "stabilizing effect" following a release in intraspecific competition; Polishchuck 1995). Daphnia may have been initially unable to buffer the impact of an earlier predation by voracious Bythotre- 


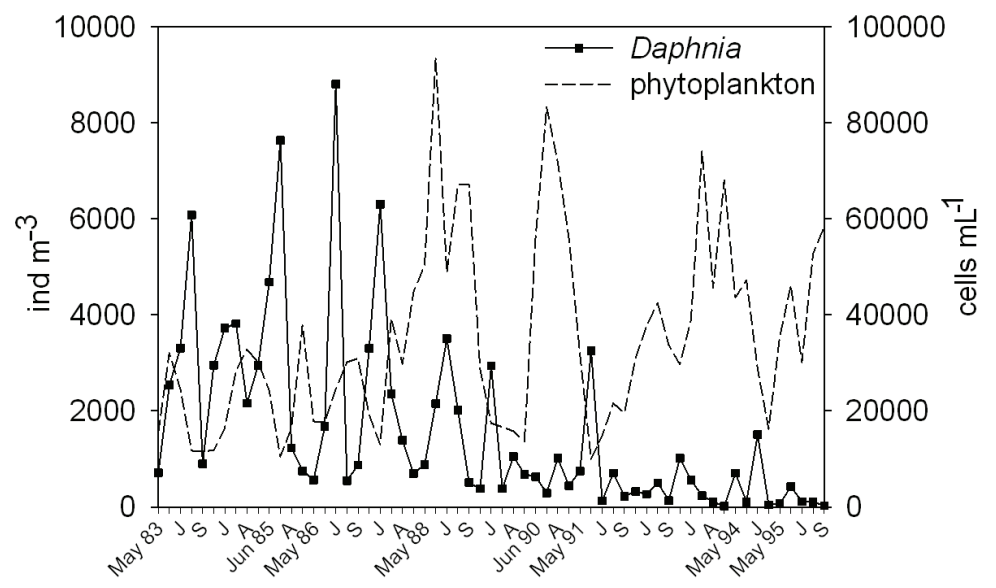

Fig. 4. Changes in Daphnia abundance (May-September) with phytoplankton cell numbers over the period 1983-1995 (from Manca \& Ruggiu 1998).

phes, which could also prey on ovigerous females (Manca et al. 2000; Manca et al. 2008). In Lago Maggiore, the strong selection by Bythotrephes on Daphnia throughout the year is also confirmed by the strong, positive correlation between the carbon isotopic signatures of the two $(r=0.89 ; \mathrm{n}=18 ; p<0.001$; Visconti \& Manca 2011). Only in winter does the Bythotrephes signature suggest that they feed mainly on cyclopoid copepods. Over the time period considered in this paper, however, the population density and biomass of copepods was not affected by the Bythotrephes increase.

The mean annual per capita mortality rate of Daphnia increased by two to three times in 1988-1990 (Fig. $3 \mathrm{~A})$ compared to previous years. The birth rate also increased, from 0.04 (in 1988) to 0.06 in 1991. It ranged between 0.02 and 0.03 in 1983-1987. During the changes in Daphnia and Bythotrephes population densities, the ratio between the two decreased sharply, from 103 Daphnia/Bythotrephes in 1983-1988 to 10 in 19891993 , decreasing further to reach a minimum of $10^{-2}$ in 1996.

During the Daphnia decline and the Bythotrephes increase (1988-1990), the colonial rotifer Conochilus unicornis-hippocrepis (gr. sensu Ruttner-Kolisko 1974) became dominant in Lago Maggiore open-water zooplankton, reaching levels of abundance never recorded before (Fig. 3B). Both the number of colonies $\times \mathrm{L}^{-1}$ and the number of individuals $\times$ colony $^{-1}$ increased, with an overall density increment of an order of magnitude compared to the years before the increase of Bythotrephes (Manca et al. 2000). As in the case of invaded lakes, Conochilus growth might have been favoured by the decrease in its main predator, Leptodora (Hovius et al. 2007), suggesting an indirect effect of the Bythotrephes increase. Throughout the season, Conochilus appeared to be able to replace Daphnia as the main particle filter feeder in the pelagia, with its maximum population density coupled to a spring increase in water transparency (Manca \& Sonvico 1996). The decline in Leptodora was only temporary, however; over the longterm, the species was able to recover, reaching since the 2000 s, levels of abundance comparable to those recorded before the Bythotrephes increase. The recovery might have also been favoured by differences in the seasonal dynamics, with Leptodora increasing in abundance when Bythotrephes is at a low density. Such a recovery led to an overall increase in invertebrate predation (Manca et al. 2000), never recorded before.

The abundance of small zooplanktonic cladocerans, i.e. Bosmina (mainly of the species Eubosmina longispina) and Diaphanosoma brachyurum, was generally lower in 1988-1990 than in the previous years when the lake was mesotrophic. They became dominant in 19911995, when the mean annual Daphnia population density was approaching its absolute minimum (in 1996; Manca et al. 2000; Fig. 1B). A similar pattern was observed as a secondary effect of the Bythotrephes invasion (Dimitru et al. 2001), although the response was delayed in the case of Lago Maggiore.

Mean annual total zooplankton biomass decreased with the Bythotrephes increase, with a high and statistically significant negative correlation between the two $(r$ $=0.79 ; p=0.001 ; \mathrm{n}=13$ ) (Fig. 3C).

During its decline in density, Daphnia body size increased (mean annual data, not measured for all years), to reach values comparable to, or slightly higher than, pre-mesotrophic values. Both the minimum size of primiparae (MSP) and the maximum size (MS) increased, particularly in 1988-1990 (Fig. 3D).

The decrease in abundance of the large filter feeder Daphnia resulted in a $>$ twofold increase in phytoplankton cell numbers (Fig. 4; from Manca \& Ruggiu 1998), which may be seen as resulting from a release in grazing pressure. Phytoplankton numbers and Daphnia density were negatively correlated at a high level of significance $(r=-0.35 ; \mathrm{n}=61 ; p<0.01)$. The cascading effect, however, was only evident when phytoplankton cell num- 
bers were used; it was not seen when phytoplankton biovolume and chlorophyll- $a$ data were tested (Manca \& Ruggiu 1998), as has been found in invaded lakes. A return to small celled phytoplankton might also be associated with oligotrophication: this does not seem the case, however, as the total biomass of phytoplankton did not decline at the same time.

\section{CONCLUSIONS}

The successful increase of Bythotrephes in the open water zooplankton of Lago Maggiore shares some of the direct and indirect effects observed from its invasion of North American sites. These include a decrease in the population density of Daphnia species, an increase in colonial rotifers and phytoplankton cell numbers, and a subsequent increase in the contribution of small cladocerans to total abundance (Yan et al. 2001). The increase was also accompanied by an overall decrease in herbivorous zooplankton biomass (Boudreau \& Yan 2003).

As in invaded lakes, the re-emergence of Bythotrephes and the overall increase of invertebrate predators in Lago Maggiore might be interpreted as increasing competition with young fish for herbivorous zooplankton (Dimitru et al. 2001). The young fish might not be compensated by the increased growth resulting from an increase in prey size. In Lago Maggiore, however, the potential increase in availability of a larger prey (Bythotrephes) was consequent not only to a higher abundance, but also to an earlier and longer growing season of its open water population.

While the mean annual per capita birth rate of Bythotrephes increased before the increase in abundance, the per capita mortality rate tended to decrease during the increase in abundance, suggesting that the hypothesis of an enhanced open water refuge was reliable. Population phenology change is also in agreement with the fact that Bythotrephes success is favoured when invasion occurs in May-July (Drake et al. 2006).

It was also of key importance for the impact on Daphnia, exposing the latter to an earlier (as early as spring and early summer) and stronger (because of the persistence of Leptodora) invertebrate predation than before. Considering all the factors, the temporary decoupling between Bythotrephes and its preferred prey observed in Lago Maggiore might be similar to the Daphnia-phytoplankton decoupling consequent to climate warming (Straile 2000).

Despite the Bythotrephes shift and the permanent increase in invertebrate predation, however, Daphnia was able to increase again since the 2000 s, reaching levels comparable to those observed before the Bythotrephes re-emergence (i.e. before 1988). Behavioural adaption mechanisms, including changes in vertical distribution might be responsible for the recovery of the system.

\section{ACKNOWLEDGMENTS}

The data used in this paper are mainly from the Monitoring Program on plankton carried out in the framework of the Research Unit on the Lago Maggiore pelagic food web, funded by the CNR and the Commission for the Protection of Italian Swiss Lago Maggiore Waters from the late 1970 s.

\section{REFERENCES}

Boudreau, S.A. \& N.D. Yan 2003. The differing crustacean zooplankton communities of Canadian Shield lakes with and without the nonindigenous zooplanktivore Bythotrephes longimanus. Can. J. Fish. Aquat. Sci., 60:1307-1313.

de Bernardi, R. 1974. The dynamics of a population of Daphnia hyalina Leydig in Lago Maggiore, Northern Italy. Mem Ist. ital. Idrobiol., 31: 221-243.

de Bernardi, R., G. Giussani \& M. Manca. 1988. Seasonal evolution of Cladocera in Lago Maggiore. (N. Italy) as influenced by environmental parameters. Verh. Internat. Verein. Limnol., 23: 530-534.

de Bernardi, R., G. Giussani, M. Manca \& D. Ruggiu. 1990. Trophic status and the pelagic system in Lago Maggiore. Hydrobiologia, 191: 1-8.

Dimitru, C., N.G. Sprules \& N.D. Yan 2001. Impact of Bythotrephes longimanus on zooplankton assemblages of Harp Lake, Canada: an assessment based on predator consumption and prey production. Freshwat. Biol., 46: 241-251.

Drake, J.M., K.L.S. Drury, D.M. Lodge, A.Blukacz, N.D. Yan \& G. Dwyer. 2006. Demographic stochasticity, environmental variability, and windows of invasion risk for Bythotrephes longimanus in North America. Biological Invasions, 8: 843-861.

Foster, S.E. \& W.G. Sprules. 2009. Effects of the Bythotrephes invasion on native predatory invertebrates. Limnol. Oceanogr., 54: 757-769.

Giussani, G. 1974. Planctofagia selettiva del coregone "bondella" (Coregonus sp.) del Lago Maggiore. Mem. Ist. ital. Idrobiol., 31: 181-203. Translated in English by FBA, Translation Series TR 122.

Grimaldi, E. 1997. Progressive decline in fish productivity from Lago Maggiore as recorded by fish catch data (19911995), p. 61-73 [in Italian]. In: A. Calderoni [Ed.]. Report of the Italian- Swiss Commission for Professional Fish Catch in Lake Maggiore Waters. Italian-Swiss Commission for the protection of the Lake Maggiore waters.

Hall, R.I. \& N.D. Yan. 1997. Comparing annual population growth estimates of ,the exotic invader Bythotrephes by using sediment and plankton records. Limnol. Oceanogr., 42: 112-120

Hovius, J.T., B.E. Beisner, K.S. McCann \& N.D. Yan. 2007. Indirect food web effect of Bythotrephes invasion: responses by the rotifer Conochilus in Harp Lake, Canada. Biological Invasions, 9: 233-243.

Ishreyet, G. 1938. Uber den Bythotrephes subalpiner Seen. Arch. Hydrobiol, XXXIV: 105-129.

Lehman, J.T. 1988. Algal biomass unaltered by food-web changes in Lake Michigan. Nature, 332: 537-538.

Leydig, F. 1860. Naturgeschichte der Daphniden (Crustacea, Cladocera). Verlag der H. Laupp'schen Buchhandlung, Tuebingen.

Manca, M. \& P. Comoli. 2000. Biomass estimates of freshwater zooplankton from length-carbon regression equations. J. Limnol., 59: 15-18.

Manca, M. \& W.R. DeMott. 2009. Response of the invertebrate predator Bythotrephes to a climate-linked increase in the duration of a refuge from fish predation. Limnol. Oceanogr., 6 (part 2): 2506-2512. 
Manca, M. \& D. Ruggiu. 1998. Consequences of pelagic food web changes during a long-term lake oligotrophication process. Limnol. Oceanogr., 43: 1368-1373.

Manca M. \& D. Sonvico. 1996. Seasonal variations in population density and size structure of Conochilus in Lago Maggiore: a biannual study. Mem. Ist. ital. Idrobiol., 54: 97-108.

Manca, M., A. Calderoni \& R. Mosello. 1992. Limnological research in Lago Maggiore: studies on hydrochemistry and plankton. Mem. Ist. ital. Idrobiol., 50: 171-200.

Manca, M., C. Ramoni \& P. Comoli. 2000. The decline of Daphnia hyalina galeata in Lago Maggiore: a comparison of the population dynamics before and after oligotrophication. Aquat. Sci., 62: 142-153.

Manca, M., J. Vijverberg, L.V. Polishchuk \& D.A. Voronov. 2008. Daphnia body size and population dynamics under predation by invertebrate and fish predators in Lago Maggiore: an approach based on contribution analysis. $J$. Limnol., 67(1): 15-21.

Manca, M., B. Torretta, P. Comoli, S. L. Amsinck \& E. Jeppesen. 2007. Major changes in trophic dynamics in large, deep subalpine Lake Maggiore from the 1940s to 2002: A high resolution comparative palaeo-neolimnological study. Freshwat. Biol. 52: 2256-2269.

Pangle, K.L, S.D. Peacor \& O.E. Johannsson. 2007. Large non lethal effects of an invasive invertebrate predator on zooplankton population growth rate. Ecology, 88: 402-412.
Ruttner-Kolisko A. 1974. Plankton rotifers. Biology and taxonomy. XXVI. Die Rotatorien. Shweizerbart'sche Verlagsbuchhandlung: $146 \mathrm{pp}$.

Sars, G.O. 1861. On the freshwater crustaceans occurring in the vicinity of Christiania. Published by the University of Bergen: $196 \mathrm{pp}$.

Straile, D. 2000. Meteorological forcing of plankton dynamics in a large and deep continental European lake. Oecologia, 122: 44-50.

Visconti, A., M. Manca \& R. de Bernardi. 2008. Eutrophication-like response to climate warming: an analysis of Lago Maggiore (N. Italy) zooplankton in contrasting years. $J$. Limnol., 67: 87-92.

Visconti, A. \& M. Manca. (2011). Seasonal changes in $\delta^{13} \mathrm{C}$ and $\delta^{15} \mathrm{~N}$ fingerprint in the pelagic food web of Lago Maggiore. J. Limnol.: (in press).

Yan, N.D. \& T.W. Pawson. 1998. Seasonal variation in the size and abundance of the invading Bythotrephes in Harp Lake, Canada. Hydrobiologia, 361: 157-168.

Yan, N.D., A. Blukacz, W.G. Sprules, P.K. Kindy, D. Hackett, R.E. Girard \& B.J. Clark. 2001. Changes in zooplankton and the phenology of the spiny water flea, Bythotrephes, following its invasion of Harp Lake, Canada. Can. J. Fish. Aquat. Sci., 58: 2341-2350. 